PRZEGLĄD NAUK HISTORYCZNYCH 2017, R. XVI, NR 1

http://dx.doi.org/10.18778/1644-857X.16.01.09

ZBigniew ANusiK

UNIWERSYTET ŁÓDZKI

\title{
Zapomniana panna Lanckorońska Przyczynek do genealogii kilku rodów kresowych
}

$\mathrm{R}$ ozważania poświęcone zapomnianej przez genealogów Annie z Brzezia Lanckorońskiej rozpocząć wypada od przedstawienia zarysu dziejów osiadłej na Podolu, możnej rodziny Świerszczów (Świrczów, Świerczów) herbu Jastrzębiec. Ostatniego męskiego potomka tego rodu poślubiła bowiem w połowie XVI stulecia tytułowa bohaterka niniejszego opracowania. Genealogie domu Świerszczów opracował swego czasu znany badacz historii Podola, Wołynia i Ukrainy, znawca dziejów szlacheckich rodów kresowych - Kazimierz Ferdynand Pułaski (1846-1926)1. Jego ustalenia w tym zakresie były jednak najczęściej pomijane przez innych historyków i genealogów, co w konsekwencji sprawiło, że w literaturze przedmiotu nadal funkcjonuje szereg bałamutnych informacji o panach na Olchowcu i Nowodworze. Przypomnijmy zatem - w ślad za K. Pułaskim - że protoplastą interesującej nas rodziny był niejaki Bedrzych (Bedrzich, Fryderyk, Bedrzyszek), być może przybysz z Czech lub Moraw, który w 1392 r. otrzymał od księcia Fedora Koriatowicza, ówczesnego pana Podola, nadanie (z prawem przekazania tych dóbr swoim spadkobiercom) czterech wiosek nad rzeka Błyszczanówką alias Tarnawka. Ten sam Bedrzych służył później

* Wydział Filozoficzno-Historyczny, Instytut Historii, Katedra Historii Nowożytnej, e-mail: zanusik@uni.lodz.pl.

1 Por. S. Konarski, Pułaski Kazimierz Ferdynand, [w:] Polski słownik biograficzny [dalej: PSB], t. XXIX, Wrocław 1986, s. 395-396. W kwestii genealogii Świerszczów (Świrczów, Świerczów) por. K. Pułaski, Stare osady w ziemi kamienieckiej i dziedziczace $w$ nich rodziny podolskiej szlachty historycznej, [w:] id e m, Szkice i poszukiwania historyczne, t. III, Kraków 1906, s. 41-81. 
wielkiemu księciu Witoldowi, od którego w latach 1414-1420 otrzymał zapisy sum zabezpieczonych na kolonizowanych dopiero ziemiach położonych nad rzeka Płoską ${ }^{2}$. Bez watpienia synem owego Bedrzycha był Mikołaj Bedrzychowicz, który w 1424 r. otrzymał od wielkiego księcia Witolda zezwolenie na zamianę swoich trzech wsi dziedzicznych na Podolu, na leżąca również w tej dzielnicy, ale w północnej jej części, na pograniczu z Wołyniem, wieś Czarny Ostrów z przyległościami. W ten sposób w ręce Świerszczów dostała się rozległa włość czarnoostrowska, którą władali (z niewielkimi przerwami) aż do wygaśnięcia rodu ${ }^{3}$.

Synem wspomnianego Mikołaja Bedrzychowicza, a wnukiem Bedrzycha, był Mikołaj Świerszcz z Nowodworu'. Po raz pierwszy odnotowano go w źródłach w 1447 r., gdy z rak Kazimierza Jagiellończyka otrzymał przywilej na użytkowanie wsi królewskiej Jaromirka w powiecie kamienieckim. W 1456 r. starosta podolski Bartłomiej Buczacki nadał mu z kolei wsie Kuźmin i Nowosiółki ${ }^{5}$. W tym samym roku Mikołaj Świerszcz otrzymał od króla (z Olechna z Jarmoliniec i wojewodą ruskim Andrzejem Odrowążem ze Sprowy)

2 Por. K. Pułaski, op. cit., s. 45-46, 48-50; S.M. Kuczyński, Fedor Koriatowicz, [w:] PSB, t. VI, Kraków 1948, s. 383. Dodajmy w tym miejscu, że spośród wiosek wymienionych w akcie wystawionym w 1392 r. przez Fedora, „z łaski Bożej kniazia i hospodara ziemi podolskiej”, z całą pewnościa możemy zidentyfikować jedynie istniejące do dziś Supruńkowce, położone w odległości ok. $20 \mathrm{~km}$ na północny wschód od Kamieńca Podolskiego.

${ }^{3}$ Por. K. Pułaski, op. cit., s. 50-51, 147-148. Przywilej wielkiego księcia Witolda (datowany w Skale 2 IX 1424 r.) zezwalający Mikołajowi Bedrzychowiczowi na przeprowadzenie wymiany dóbr, dzięki której Świerszczowie weszli w posiadanie Czarnego Ostrowa, został potwierdzony na prośbę jego prawnuczki - Konstancji Świerszczówny z Nowodworu przez Zygmunta Augusta aktem wystawionym w Krakowie 17 II 1553 r. Por. Archiwum Główne Akt Dawnych w Warszawie [dalej: AGAD], Metryka Koronna [dalej: MK] 82, f. 496v-497v. Por. też Matricularum Regni Poloniae summaria, excussis codicibus, qui in Chartophylacio Maximo Varsoviensi asservantur [dalej: MRPS], t. V, cz. 2, wyd. J. Płocha, A. Rybarski, I. Sułkowska, red. J. Sawicki, Warszawa 1961, nr 5994.

${ }^{4}$ W znanych nam zapiskach źródłowych występował on jako Nicolaus Swircz de Byedrzichowcze, Nicolaus Byedrzich, Nicolaus Byedrzych oraz Nicolaus de Nowidwor. Por. AGAD, MK 11, f. 85, 381; MK 12, f. 71, 171, MK 14, f. 350. Główna posiadłościa Mikołaja Świerszcza było późniejsze miasteczko Gródek, zwane ówcześnie Bedrzchowcami lub Bedrzychowem. W pobliżu Gródka Świerszczowie zbudowali nowy zamek, czyli Nowodwór, skąd pisał się zarówno Mikołaj, jak i jego synowie. Por. K. Pułaski, op. cit., s. 43-44, 52. W pochodzącym z 1453 r. spisie miast ziemi podolskiej Gródek występuje pod nazwą Byedrzichowcze. Por. AGAD, MK 11, f. 10; MRPS, t. I, wyd. T. Wierzbowski, Warszawa 1905, nr 192.

${ }^{5}$ K. Pułaski, op. cit., s. 52. 
zapis 100 grzywien na jednej $z$ wiosek domeny monarszej nad rzeką Uszyca ${ }^{6}$. W styczniu 1458 r. Kazimierz Jagiellończyk dokonał na jego rzecz kolejnego zapisu w wysokości 100 grzywien zabezpieczonych na wsi Kujałów7 ${ }^{7}$. W 1469 r. Mikołaj Świerszcz z Nowodworu został kasztelanem kamienieckim ${ }^{8}$. W kwietniu roku 1472 król zapisał mu 50 grzywien na Jaromirce ${ }^{9}$. W marcu 1474 r. kasztelan otrzymał natomiast konsens królewski na wykupienie wsi Zielińce $\mathrm{w}$ powiecie kamienieckim $\mathrm{z}$ rak Domarata $\mathrm{z}$ Szarawki ${ }^{10}$. W 1479 r. Mikołaj z Nowodworu z żona Elichna przekazał donację na rzecz klasztoru dominikanów w Kamieńcu Podolskim, co zdaje się potwierdzać przypuszczenie K. Pułaskiego, że Świerszczowie od chwili pojawienia się na Podolu byli katolikami ${ }^{11}$. Po raz ostatni wspomniano Mikołaja z Nowodworu w styczniu 1490 r., gdy król zapisał mu kolejnych 60 grzywien na dobrach Jaromirka i Kujałów ${ }^{12}$. Kasztelan kamieniecki doczekał się bardzo licznego potomstwa - pięciu synów i czterech córek ${ }^{13}$. Nas interesuja jednak jedynie dwaj synowie Mikołaja Świerszcza $z$ Nowodworu $z$ jego małżeństwa $z$ Elichna, którzy przeżyli zmarłych bezpotomnie braci i w 1496 r. dokonali działu majętności po ojcu. Byli to Andrzej, podkomorzy kamieniecki, oraz Michał. Młodszy z nich - Michał, zmarł wkrótce po przeprowadzeniu aktu podziałowego. Pozostawił po sobie jedynie dwie córki - Beatę $1^{\circ} \mathrm{v}$. Stanisławową Górską $2^{\circ} \mathrm{v}$. Mikołajową Świkowską, cześnikową kamieniecką, oraz nieznana z imienia, pierwszą żonę Mikołaja Herburta z Fulsztyna,

${ }^{6}$ Por. AGAD, MK 11, f. 85; MRPS, t. I, nr 291. W przywileju królewskim datowanym w Krakowie 23 IV 1456 r. mowa jest o wsi Vyczmicze nad rzeka Uszicze.

7 Por. AGAD, MK 11, f. 351; MRPS, t. I, nr 472. Cytowany tu dokument został wystawiony w Sandomierzu 9 I 1458 r. Zapis dotyczy wsi Cuyalewo w powiecie (okręgu) smotryckim (districtus Smotrzycensis).

8 Por. K. Pułaski, op. cit., s. 53.

9 Por. AGAD, MK 12, f. 71; MRPS, t. I, nr 813; K. Pułaski, op. cit., s. 52.

${ }_{10}$ Por. AGAD, MK 12, f. 171; MRPS, t. I, nr 1151.

11 Por. K. Pułaski, op. cit., s. 53, 152-153.

12 Por. AGAD, MK 14, f. 350; MRPS, t. I, nr 2094; K. Pułaski, op. cit., s. 52 i 62 (tu wzmianka, że kasztelan kamieniecki żył jeszcze w 1492 r., gdy dokonać miał zastawu części Bedrzychowiec).

${ }^{13}$ Wszystkie dzieci Mikołaja Świerszcza $z$ Nowodworu wymienione zostały w pochodzącym z 1479 r. dokumencie potwierdzającym dokonanie przez niego zapisu na rzecz klasztoru dominikanów w Kamieńcu Podolskim. Z układu jego treści można wnioskować, że $z$ pierwszą, nieznaną $z$ imienia żoną kasztelan kamieniecki miał syna Jakuba. Matka pozostałych dzieci, czyli synów - Andrzeja, Michała, Floriana i Feliksa oraz córek - Małgorzaty, Jadwigi, Elżbiety i Beaty była natomiast druga żona Świerszcza - Elichna. Por. K. Puła ski, op. cit., s. 152. 
wojskiego kamienieckiego i starosty barskiego. Obie córki Michała Świerszcza zmarły najpewniej bezpotomnie. Majattki odziedziczone po ojcu przez Beatę Swikowska wróciły z czasem do córek jej stryja Andrzeja. Większość dóbr drugiej córki Michała $z$ Nowodworu pozostała natomiast w rękach Herburtów, czyli rodziny jej męża ${ }^{14}$.

Drugi $z$ kasztelaniców kamienieckich - Andrzej, podkomorzy kamieniecki, był ostatnim męskim potomkiem Świerszczów na Nowodworze. Ożeniony z Zofią de Werzykowce, podobnie jak brat Michał pozostawił po sobie jedynie dwie córki. Zmarł najpewniej w 1511 r. Nie żył już na pewno w 1512 r., gdy jako opiekun jego córek występował przedstawiciel drugiej linii rodziny - choraży kamieniecki Adam Świerszcz z Olchowca. Córkami podkomorzego Andrzeja były Anna i Konstancja. Pierwsza $z$ nich przed 1524 r. wyszła za maż za Mikołaja Romanowskiego. Owdowiawszy po pierwszym mężu, poślubiła Macieja z Hermanowa Włodka

${ }^{14}$ Por. K. Pułaski, op. cit., s. 55-56, 59-61. Warto w tym miejscu odnotować, że scheda po kasztelanie kamienieckim obejmowała zamek i miasteczko Nowodwór (Gródek) oraz ok. 30 wsi, z których część należała do dóbr domeny królewskiej. Na dział starszego $z$ braci - Andrzeja przypadła połowa zamku i miasta Gródka oraz kilkanaście wsi z Kujałowem, Bedrzychowcami, Czarnym Ostrowem i Płoskirowem. Młodszy z braci - Michał objął drugą połowę zamku i miasta Nowodworu oraz dział obejmujacy pozostałe wsie ojcowskie $z$ Jaromirka, Kupinem, Kuźminem i Dobrohoszczą. Dobra po Michale zostały podzielone między jego dwie córki. $Z$ cała pewnością możemy stwierdzić, że Beata nie pozostawiła po sobie potomstwa, a jej dobra $z$ czasem przeszły w posiadanie córek Andrzeja Świerszcza. Trudno natomiast odpowiedzieć na pytanie, dlaczego pozostałe majątki Michała z Nowodworu zostały przejęte przez Herburtów. Kazimierz Pułaski wysunął przypuszczenie, że nieznana $z$ imienia, druga córka Michała Świerszcza została żona Mikołaja Herburta, wojskiego kamienieckiego, który dzięki temu został właścicielem połowy Gródka i szeregu wsi należących do tej włości. Por. idem, op. cit., s. 60-61. Sądzić wypada, że tak było w istocie. Wydaje się sprawą oczywista, że Mikołaj Herburt otrzymał od swojej żony zapis dożywocia na jej dobrach, które przez następnych kilkadziesiąt lat trzymał w swoich rękach. Przed 16 III 1512 r. ożenił się natomiast po raz drugi $z$ Elżbietą $z$ Chodorostawu Chodorowska herbu Korczak (został odnotowany $z$ żona jako strona $\mathrm{w}$ procesie ziemian podolskich z miastem Kamieńcem Podolskim). Por. AGAD, MK 25, f. 144-144v; MRPS, t. IV, wyd. T. Wierzbowski, Warszawa 1917, nr 1491. Ze zwiąku tego doczekał sie dwóch synów i córki. Jedyną możliwością zatrzymania przez Herburtów dóbr po pierwszej żonie Mikołaja było ich wykupienie od jej spadkobierców. I rzeczywiście, wojski kamieniecki sukcesywnie nabywał od Świerszczów kolejne wioski, które trzymał dotąd tytułem dożywocia. Wydaje się, że do 1530 r. zdobył pełne prawo własności na wszystkie dobra wniesione mu przez córkę Michała Świerszcza z Nowodworu. W tym bowiem roku Zygmunt I Stary odnowił przywilej na pobieranie cła w dobrach Gródek i Bedrzychów należących do Mikołaja Herburta, wojskiego kamienieckiego. Por. AGAD, MK 45, f. 159-159v. 
herbu Sulima, z czasem chorążego i starostę kamienieckiego. Druga $z$ córek Andrzeja - Konstancja wyszła za mąż za syna swojego opiekuna - Jana Świerszcza $z$ linii na Olchowcu. Co ciekawe, dopiero w 1545 r. córki zmarłego przed ponad 30 laty Andrzeja dokonały podziału spadku po ojcu. Annie Włodkowej przypadła wówczas w udziale rozległa włość czarnoostrowska (zamek, miasto i kilkanaście wsi), a Konstancja Świerszczowa otrzymała część włości gródeckiej i inne posiadłości należące niegdyś do podkomorzego kamienieckiego. Anna ze Świerszczów Włodkowa zmarła bezpotomnie kilka lat po dokonaniu aktu działowego. Wkrótce potem jej siostra podjęła energiczne zabiegi o odzyskanie Czarnego Ostrowa, na którym owdowiały Maciej Włodek miał zagwarantowane dożywocie. Starania te zakończyły się powodzeniem w 1554 r., gdy zawarto ugodę, na mocy której Włodek otrzymał na własność trzy wsie $z$ klucza czarnoostrowskiego, a reszta włości wróciła do rąk Konstancji ze Świerszczów Świerszczowej" ${ }^{15}$.

Protoplasta linii Świerszczów na Husiatynie i Olchowcu był drugi syn Bedrzycha, Jurko (Jerzy) Świrczowicz, który w 1431 r. otrzymał od Władysława Jagiełły nadanie wsi Bałwaniec nad rzeka o tej samej nazwie ${ }^{16}$. Jednym $z$ synów Jerzego Świrczowicza był Jan Świerszcz z Wachnowiec i Husiatyna, zmarły po 1475 r. Z nieznanej nam żony pozostawił on córki Zofię i Helenę oraz syna Ada$\mathrm{ma}, \mathrm{w} 1482 \mathrm{r}$. odnotowanego $\mathrm{z}$ godnością stolnika kamienieckiego, a w latach 1512-1518 występującego $z$ urzędem chorążego kamienieckiego ${ }^{17}$. W 1512 r. Adam Świerszcz z Olchowca objął opiekę nad córkami podkomorzego kamienieckiego Andrzeja Świerszcza z Nowodworu. W 1518 r. otrzymał potwierdzenie prawa do użytkowania wsi królewskich Kutkowce i Bałwaniec oraz dodatkowy zapis

15 Por. K. Pułaski, op. cit., s. 61-66. Dodajmy w tym miejscu, że wdowa po Andrzeju Świerszczu z Nowodworu wyszła za mąż za Jana Katholta (Katolta), z którym miała córkę Beatę, żonę Andrzeja Bąka Lanckorońskiego. Warto też wspomnieć, że Zofia Katholtowa odprzedała Bedrzychowce (przy czym chodzi tu raczej o wieś w okolicach Gródka, a nie o sam Gródek) skupujacemu konsekwentnie dawne posiadłości Świerszczów, właścicielowi części Gródka (Nowodworu), wojskiemu kamienieckiemu Mikołajowi Herburtowi. Por. ibidem, s. 62.

16 Por. ibidem, s. 51-52.

17 Por. ibidem, s. 67-68. Dodajmy również, że jedna $z$ córek Jana Świerszcza z Olchowca - Zofia była żoną Zygmunta Niezborskiego, a druga - Helena poślubiła najpierw Mikołaja Kuropatwę, a po jego śmierci wyszła za Andrzeja Nieświckiego. Por. ibidem, s. 67; AGAD, MK 25, f. 144-144v (tu, w dokumencie datowanym na 16 III 1512 r., chorąży kamieniecki Adam Świerszcz został wymieniony jako jeden z uczestników sporu $z$ mieszczanami kamienieckimi). 
na tych wsiach $z$ prawem dożywocia dla synów Stanisława i Jana. W tym samym roku uzyskał przywilej królewski na prawo magdeburskie dla miasteczka Zawala, swojej posiadłości dziedzicznej pod Kamieńcem ${ }^{18}$. Sądzić wypada, że chorąży kamieniecki Adam Świerszcz z Olchowca zmarł w roku 1518 lub też wkrótce potem. Był żonaty $z$ Wichna $z$ Niżnego Stawu, $z$ która miał troje dzieci. Wspomnianych synów Stanisława i Jana oraz córkę Annę, która poślubiła Jana Dzietrzycha (Dzietrzicha). Zdaniem K. Pułaskiego starszy syn Adama - Stanisław był protoplasta rodziny Świrczowskich i obją dobra ojcowskie położone głównie w województwie ruskim. Młodszy z synów chorą̇̇ego kamienieckiego - Jan odziedziczył natomiast po ojcu dobra podolskie i tu rozwijał swoja działalność. W roku 1524, jak również dwa lata później, „chorążyc” Jan Świerszcz uczestniczył jako sędzia w roczkach sądowych kamienieckich. Był już w tym czasie zapewne mężem Konstancji Świerszczówny z Nowodworu, pupilki swojego ojca, która zdążył poślubić być może jeszcze przed jego śmiercia. W 1539 r. Jan Świerszcz z Olchowca dokonał zamiany dóbr, czyli "frymarku” z królową Boną. W zamian za wieś dziedziczną Manikowce, bez której „się zamek barski obejść nie mógł”, otrzymał prawo dziedziczne na wsie królewskie Husiatyn, Kutkowce i Bałwaniec, które trzymał dotychczas „w starych sumach" ${ }^{19}$.

Warto zwrócić uwage na to, że nieuregulowane prawo własności do dóbr ziemskich na Podolu wikłało tamtejszych ziemian w różnego rodzaju spory prawne. Często trudno było ustalić status danej miejscowości, która równie dobrze mogła być własnością dziedziczną, jak też trzymaną w formie zastawu królewszczyzną. Tego rodzaju problemy dotykały również rodzinę Świerszczów. Wiosna 1552 r. kilku kresowych wielmożów podjęło próbę przejęcia części należących do nich majątków. Dnia 31 maja tego roku wojewodzic podolski Jan Kamieniecki uzyskał konsens królewski na wykupienie (uznanego w kancelarii koronnej za królewszczyznę) Czarnego Ostrowa $z$ przyległymi wsiami $z$ rąk Konstancji, żony Jana Świersz$\mathrm{cza}^{20}$. O podobna zgodę na wykupienie kilku innych wsi królewskich z rąk Konstancji Świerszczowej wystarał się również jej szwa-

${ }_{18}$ Por. K. Pułaski, op. cit., s. 63, 68-69; AGAD, MK 30, f. 209v.

19 Por. K. Pułaski, op. cit., s. 69; AGAD, MK 58, f. 286-290 (tu akt nadania Janowi Świerszczowi na własność Husiatyna, Kutkowiec i Bałwańca oraz dokument potwierdzający przeprowadzenie wspomnianej wymiany dóbr i przyłączenie wsi Manikowce do domeny królewskiej).

20 Por. AGAD, MK 82, f. 259-260 (Gostynin 31 V 1552); MRPS, t. V, cz. 2, nr 5789. 
gier, Maciej z Hermanowa Włodek, chorąży i starosta kamieniecki, który właśnie w tym czasie procesował się $z$ nią o włość czarnoostrowską ${ }^{21}$. Kiedy zaś latem 1552 r. na dwór królewski dotarła fałszywa wiadomość o śmierci Jana Świerszcza, zgodę monarchy na wykupienie kolejnych wsi domeny od Konstancji, wdowy po zmarłym jakoby dziedzicu Husiatyna i Olchowca, dostał również wojewoda podolski Jan Mielecki ${ }^{22}$. W tej sytuacji sądzić wypada, że $z$ osoba Jana juniora, jedynego syna Jana i Konstancji Świerszczów łączyć należy wystąpienie Piotra Kmity, wojewody krakowskiego i marszałka wielkiego koronnego, za wstawiennictwem którego kilka dni później król utwierdził Jana Świerszcza w posiadaniu wsi Płoska w powiecie kamienieckim ${ }^{23}$. Kiedy jednak po jakimś czasie okazało się, że Jan Świerszcz senior nadal cieszy się dobrym zdrowiem, Zygmunt August w marcu 1553 r. potwierdził jego prawo do dożywotniego użytkowania siedmiu wsi królewskich w powiecie kamienieckim, które od dawna pozostawały w rękach rodziny Świerszczów. W tym samym akcie król przyznał też prawo do dożywocia na tych dobrach synowi Jana Świerszcza seniora, Janowi Świerszczowi juniorowi ${ }^{24}$.

W 1554 r. Jan i Konstancja Świerszczowie zawarli z Maciejem Włodkiem ugodę w sprawie ostatecznego przejęcia przez nich dóbr czarnostrowskich. Dwa lata później król, na prośbę Konstancji Świerszczowej, której praw własności do tej majętności tym razem nikt już nie kwestionował, nadał prawa miejskie Czarnemu

${ }^{21}$ Por. AGAD, MK 82, f. 260-261 (Gostynin 31 V 1552); MRPS, t. V, cz. 2, nr 5790.

${ }^{22}$ Por. AGAD, MK 80, f. 312v-313 (Gdańsk 27 VIII 1552); MRPS, t. V, cz. 2, nr 1353.

${ }^{23}$ Por. AGAD, MK 80, f. 328v (Malbork 2 IX 1552); MRPS, t. V, cz. 2, nr 1373.

${ }_{24}$ Por. AGAD, MK 83, f. 132v (Kraków 23 III 1553); MRPS, t. V, cz. 1, wyd. T. Wierzbowski, Warszawa 1919, nr 1511. Warto może tu dodać, że na tym nie zakończyły się bynajmniej kłopoty Świerszczów z pretendentami do przejęcia należących do nich od kilku pokoleń majątków. W styczniu 1554 r. zgodę królewska na wykupienie $z$ rak Jana Świerszcza wsi Bałwaniec $z$ przyległościami dostał bowiem, z prawem dożywocia na tych dobrach, Paweł Skotnicki. W kwietniu tego samego roku konsens na wykupienie połowy wsi Płoska $z$ rak Konstancji Świerszczowej i Macieja Włodka (z prawem dożywocia i zapisem 200 grzywien) dostał $z$ kolei Stanisław Nadolski, pisarz ziemski kamieniecki. Nie oznacza to rzecz jasna, że Świerszczowie dopuścili do realizacji tych nadań. Niemniej jednak $z$ pewnościa znowu musieli wystapić na droge prawna albo też $\mathrm{w}$ inny sposób zaspokoić pretensje Skotnickiego i Nadolskiego. Por. AGAD, MK 84, f. 412v-413 (Knyszyn 10 I 1554); MK 86, f. 188v-190 (Lublin 18 IV 1554); MRPS, t. V, cz. 2, nr 6457, 6631. 
Ostrowowi ${ }^{25}$. W tym samym roku Zygmunt August potwierdził prawa jej męża do dziedzicznego władania wsią Milejowce ${ }^{26}$. W 1559 r. Jan Świerszcz z Olchowca wystarał się z kolei o prawa miejskie dla należącego do niego Husiatyna ${ }^{27}$. Ostatnie wzmianki o Janie Świerszczu seniorze pochodzą z 1561 r. Wtedy właśnie zawarł on bowiem odnotowaną w źródłach umowę dotyczącą ściągnięcia osadników do należącej do niego wioski Kutkowce ${ }^{28}$. Jesienia tego samego roku Mikołaj Potocki, zarządca zamku kamienieckiego i rotmistrz jazdy obrony potocznej, protoplasta magnackiej linii tego rodu, uzyskał natomiast konsens królewski na wykupienie $z$ rąk Jana Świerszcza wsi królewskiej Czubarowce ${ }^{29}$. Sądzić wypada, że Jan Świerszcz senior oraz jego żona Konstancja zmarli wkrótce potem, być może jeszcze w 1561 r., najpóźniej zaś w roku 1563.

Jedynym synem tej pary był Jan Świerszcz junior. Nie znamy, co prawda, daty ślubu jego rodziców, ale możemy przypuszczać, że urodził się pod koniec pierwszej ćwierci XVI stulecia. To właśnie on został mężem tytułowej bohaterki niniejszego szkicu, Anny z Brzezia Lanckorońskiej herbu Zadora, córki Hieronima, starosty skalskiego. Zgodnie $z$ ustaleniami K. Pułaskiego w 1556 r. Jan Świerszcz junior otrzymał od rodziców cesję dóbr czarnoostrowskich, na których miał zabezpieczyć posag swojej żony. Dodatkowo matka przekazała mu wówczas części we wsiach Jaromirka, Kujałów i Szyszkowce, a teść, Hieronim Lanckoroński, zapisał mu 1000 złp zabezpieczonych na Grodkowcach i innych jego dobrach. Ze swojej strony młody Świerszcz zeznał, że otrzymał 1500 złp posagu swojej żony, które z 1500 złp wiana oprawił na otrzymanych od rodziców dobrach. Zobowiązał się również stawić swoją małżonkę na najbliższych roczkach sądowych w Kamieńcu Podolskim, gdzie Anna $z$ Brzezia miała potwierdzić, że jest satisfacta de bonis paternis ${ }^{30}$.

${ }^{25}$ Por. AGAD, MK 89, f. 8-9v (akt nadania prawa magdeburskiego dla Czarnego Ostrowa, datowany w Warszawie na 22 X 1556 r.); MRPS, t. V, cz. 2, nr 7627.

${ }^{26}$ Por. AGAD, MK 89, f. 125v (odbiorca przywileju wystawionego w Warszawie 31 XII 1556 r., obok Jana Świerszcza z Olchowca, był również jego szwagier, Jan Dzietrzych).

27 Por. K. Pułaski, op. cit., s. 70-71; AGAD, MK 93, f. 122-123v (akt nadania prawa magdeburskiego dla Husiatyna datowany w Piotrkowie 5 I 1559 r.); MRPS, t. V, cz. 1, nr 2382.

28 Por. K. Pułaski, op. cit., s. 70.

29 Por. AGAD, MK 95, f. 553v-554 (Wilno 28 X 1561); MRPS, t. V, cz. 1, nr 9018. Por. też M. Plewczyński, Potocki Mikołaj, [w:] PSB, t. XXVIII, Wrocław 19841985, s. 103-105.

${ }^{30}$ Por. K. Pułaski, op. cit., s. 74-75. 
Jedno nie ulega zatem najmniejszej wattpliwości. Hieronim $z$ Brzezia Lanckoroński (zm. 1569) miał córkę Annę, którą wydał za Jana Świerszcza juniora, syna Jana Świerszcza z Olchowca i Konstancji Świerszczówny z Nowodworu. Jedyne, co może zastanawiać, to fakt, $\dot{z}$ e ta córka Hieronima nie została odnotowana w żadnej genealogii rodu $z$ Brzezia Lanckorońskich. Brakuje jakiejkolwiek wzmianki o Annie Lanckorońskiej w herbarzach Kaspra Niesieckiego ${ }^{31}$, Adama Bonieckiego ${ }^{32}$ i Seweryna Uruskiego ${ }^{33}$. Nie wie o jej istnieniu również Włodzimierz Dworzaczek ${ }^{34}$. Co jednak wydaje się najbardziej zaskakujące, nie pojawia się ona również na kartach najnowszego opracowania dziejów rodu Lanckorońskich pióra Stanisława Cynarskiego ${ }^{35}$.

W tym miejscu wypada przybliżyć nieco osobę Anny z Brzezia Lanckorońskiej. Wiemy już, że jej ojcem był Hieronim z Brzezia Lanckoroński (zm. 6 stycznia 1569), w latach 1535-1566 starosta skalski, który był jedynym synem Mikołaja (zm. 1520), cześnika i burgrabiego krakowskiego, oraz Katarzyny ze Stadnickich, wojewodzianki bełskiej ${ }^{36}$. Matka naszej bohaterki była $z$ kolei Katarzyna Niemścianka $z$ Krzcięcic herbu Jastrzębiec, pierwsza żona Hieronima Lanckorońskiego (jego druga żoną była poślubiona przed 1551 r. Anna Iskrzycka, wdowa po Janie Jordanie). Adam Boniecki podaje, że Katarzyna z Niemstów Lanckorońska była córką Jerzego Niemsty. Stanisław Cynarski twierdzi natomiast, że ojcem Katarzyny był Jan Niemsta $z$ Krzcięcic ${ }^{37}$. Twierdzenie to nie ma jednak żadnych podstaw źródłowych ${ }^{38}$. W moim głębokim przekonaniu

${ }^{31}$ Por. K. Niesiecki, Herbarz polski, wyd. J.N. Bobrowicz, t. VI, Lipsk 1841, s. 8-9.

${ }^{32}$ Por. A. Boniecki, Herbarz polski, t. XIII, Warszawa 1909, s. 335 (tu informacja, że być może córka Hieronima Lanckorońskiego była Jadwiga, żona Hieronima Czyżowskiego).

${ }^{33}$ Por. S. Uruski, A.A. Ko siński, A. Włodarski, Rodzina. Herbarz szlachty polskiej, t. VIII, Warszawa 1911, s. 270.

${ }^{34}$ Por. W. Dworzaczek, Genealogia, t. II (Tablice), Warszawa 1959, tabl. 101.

35 Por. S. Cynarski, Dzieje rodu Lanckorońskich z Brzezia od XIV do XVIII wieku. Sprawy kariery urzędniczej i awansu majątkowego, Warszawa-Kraków 1996, s. 125-127 (tu na s. 127 także wspomniano o Jadwidze, żonie Hieronima Czyżowskiego, jako o domniemanej córce Hieronima Lanckorońskiego).

${ }^{36}$ Por. I. Kaniews ka, Lanckoroński Mikołaj, [w:] PSB, t. XVI, Wrocław-Warszawa-Kraków 1971, s. 446-448; S. Cynarski, op. cit., s. 125-127; A. B oniecki, op. cit., t. XIII, s. 335.

${ }^{37}$ Por. A. Boniecki, op. cit., t. XIII, s. 335; S. Cynarski, op. cit., s. 127.

38 Stanisław Cynarski powołuje się na tablice W. Dworzaczka, który w ogóle nie podaje imienia ojca Katarzyny Niemścianki. Istnieje jednak dokument, nieznany 
Katarzyna Niemścianka była córką Jerzego Niemsty z Krzcięcic i jego pierwszej żony, Barbary Gołuchowskiej z Grodziny herbu Lis, która jako żona Jerzego była odnotowywana w źródłach w latach 1516-1527 ${ }^{39}$. Możemy zatem założyć, że Katarzyna Niemścianka z Krzcięcic mogła przyjść na świat już w roku 1517 lub 1518. Za Lanckorońskiego wyszła najpewniej w połowie lat trzydziestych XVI w. Oznacza to, że Anna Lanckorońska, będąca prawdopodobnie najstarszym dzieckiem Hieronima i Katarzyny, urodziła się w 1536 lub też w $1537 \mathrm{r}^{40}$ Informacja ta jest o tyle istotna, że jej małżeństwo $z$ Janem Świerszczem $z$ Olchowca $z$ cała pewnością zostało zawarte wcześniej niż w roku 1556, gdy uregulowano jedynie wszystkie kwestie związane $z$ wypłatą i zabezpieczeniem jej posagu. Ze względu na datę urodzenia Anny należy jednak założyć, że nie nastapiło to wcześniej niż w roku 1553.

W małżeństwie $z$ Janem Świerszczem Anna Lanckorońska urodziła dwie córki - Annę Elżbietę (Halszkę) i Katarzynę. Owdowiała najpóźniej w 1563 r., gdy nie żył już zarówno jej mąż, jak i teść - Jan Świerszcz senior. W 1563 r. opiekę nad jej nieletnimi córkami objął bowiem kasztelan kamieniecki Jerzy Jazłowiecki. W marcu 1564 r.,

S. Cynarskiemu, na podstawie którego można by uznać, że Katarzyna Niemścianka rzeczywiście była córka Jana. W 1549 r. Zygmunt August potwierdził bowiem fakt ustanowienia przez Jerzego Niemstę opieki nad jego nieletnimi dziećmi $z$ drugiego małżeństwa $z$ Reginą Glińska. Wśród wyznaczonych wówczas opiekunów wymieniono również Hieronima Lanckorońskiego, którego określono mianem „Szwagra” Jerzego Niemsty. Por. Słownik historyczno-geograficzny województwa krakowskiego w średniowieczu, cz. 3, z. 1, oprac. W. Bukowski, J. Kurtyka, J. Laberschek, Z. Leszczyńska-Skrętowa, F. Sikora, red. F. Sikora, Kraków 1994, s. 182. Jest to jednak ewidentna pomyłka wydawców lub też pisarza sporządzającego ten dokument, gdyż Lanckoroński był nie szwagrem, ale zięciem Jerzego Niemsty. Jest bowiem bardzo mało prawdopodobne, aby urodzony na przełomie XV i XVI w. Hieronim (jego rodzice pobrali się najpewniej w 1496 r.) zdecydował się na ślub ze znacznie starszą od siebie córka zmarłego już w 1488 r. Jana Niemsty.

${ }^{39}$ Por. Słownik historyczno-geograficzny..., cz. 3, z. 1, s. 182.

${ }^{40}$ Dodajmy w tym miejscu, że Katarzyna $z$ Niemstów Lanckorońska była również matka rodzonych braci Anny - Stanisława (zm. 1592), kasztelana halickiego, oraz Mikołaja (zm. 1597), podkomorzego podolskiego. Informacja o tym, że jeszcze jednym dzieckiem Hieronima i Katarzyny Lanckorońskich była Jadwiga, żona Hieronima Czyżowskiego, jest niepewna i wymaga potwierdzenia źródłowego. Co ciekawe, autor biogramów Stanisława i Mikołaja Lanckorońskich w PSB - Henryk Kotarski w ogóle nie wspomina o ich matce. Por. A. Boniecki, op. cit., t. XIII, s. 335-336; S. Uruski, A.A. Kosiński, A. Włodarski, op. cit., t. VIII, s. 270; W. Dworzaczek, op. cit., t. II, tabl. 101; H. Kotarski, Lanckoroński Mikołaj, [w:] PSB, t. XVI, s. 448; i d e m, Lanckoroński Stanisław, [w:] ibidem, s. 452-453. 
podczas obrad sejmu w Warszawie, zaaprobowano i potwierdzono dopuszczenie przez Jazłowieckiego do opieki nad Anną Elżbietą i Katarzyną Świerszczównami również ich dziadka, starostę skalskiego Hieronima Lanckorońskiego ${ }^{41}$. Zapewne w tym samym czasie Anna z Brzezia wyszła ponownie za mąz, poślubiając nieznanego $z$ imienia przedstawiciela osiadłego na Podolu rodu Piaseckich herbu Janina. W rejestrze poborowym województwa podolskiego z 1565 r. odnotowano bowiem, że właścicielka Czarnego Ostrowa oraz kilkunastu wsi tej włości, na której zabezpieczony był posag Anny, jest pani Piasecka alias Swiersczowa ${ }^{42}$. Być może $z$ faktem poślubienia przez Annę Lanckorońską któregoś z Piaseckich łączyć należy wydarzenie, które wywołać musiało niemałą sensację w środowisku ziemian podolskich. Otóż jej starsza córka - Anna Elżbieta (Halszka) została porwana przez jednego $z$ konkurentów do jej ręki - Floriana Piaseckiego. Wydarzenie to miało miejsce gdzieś na przełomie roku 1563 i 1564. Nie wydaje się jednak możliwe, aby Piasecki mógł zgodnie $z$ wymogami prawa poślubić swoją brankę. W owym czasie Halszka Świerszczówna, która urodziła się zapewne nie wcześniej niż w 1554 lub też w 1555 r., mogła mieć co najwyżej ok. 10 lat. To ułatwiło działania opiekunów Anny Elżbiety, którzy w 1564 r. odebrali ja Piaseckiemu i „dali do chowania” pewnym osobom na trzy lata. Opisujacy te wydarzenia K. Pułaski nie zwrócił uwagi na to, że było to w istocie porwanie dziecka, a owe trzy lata były potrzebne do tego, aby Halszka Świerszczówna osiagnęła wiek sprawny, w którym, przynajmniej teoretycznie, mogła samodzielnie zdecydować o swoich losach. Dopiero w 1567 r. Jerzy Jazłowiecki i Hieronim Lanckoroński stawili więc 12-, 13-letnią Annę Elżbietę przed sadem grodzkim we Lwowie, gdzie na pytanie, czy chce pozostawać w (z pewnościa nieskonsumowanym) związku małżeńskim z Florianem Piaseckim, Świerszczówna odpowiedziała przecząco ${ }^{43}$. Należy zwrócić uwage na to, że sprawa porwania Halszki nie była wcale jednoznaczna i oczywista. Jego sprawca nie poniósł bowiem żadnej kary i jak się wydaje, opiekunowie małej Świerszczówny

${ }^{41}$ Por. K. Pułaski, op. cit., s. 75; AGAD, MK 96, f. 333v-334 (Warszawa 14 III 1564); MRPS, t. V, cz. 2, nr 9381.

${ }^{42}$ Por. K. Pułaski, op. cit., s. 75; Źródła dziejowe, t. XIX (Polska XVI wieku pod wzgleddem geograficzno-statystycznym), t. VIII (Ziemie ruskie. Wołyń i Podole), wyd. A. Jabłonowski, Warszawa 1889, s. 178. Dodajmy, że Anna z Lanckorońskich Piasecka władała w 1565 r. dobrami składajacymi się z miasta Czarnego Ostrowa i 12 wsi. Por. Źródła dziejowe, t. XIX, s. 178, 185-186, 191.

${ }^{43}$ Por. K. Pułaski, op. cit., s. 75-76. 
nie wystapili przeciwko niemu na drogę sądowa. Co więcej, w 1566 r. na sejmie w Lublinie Zygmunt August zezwolił Florianowi Piaseckiemu na wykupienie wsi Psiec w powiecie kamienieckim $z$ rąk Kaspra Wilkowskiego i potwierdził mu zapis 30 grzywien $z$ prawem dożywocia na częściach wsi Bakota, Uście i Rumkosów oraz na całej wsi Kucza w województwie podolskim ${ }^{44}$. To z kolei pozwala nam przypuszczać, że za sprawą niedoszłego zamęścia Halszki stała Anna z Brzezia, z przyzwoleniem której działał „porywacz” jej starszej córki ${ }^{45}$.

Warto może przy tej okazji prześledzić dalsze losy córek Anny Lanckorońskiej. Starsza $z$ nich poślubiła Konstantego ks. Wiśniowieckiego, w latach 1571-1574 starostę żytomierskiego. Ślub młodej pary odbył się zapewne w 1569 r. W rejestrze poborowym województwa podolskiego $z 1569 \mathrm{r}$. odnotowano bowiem własność kniazia Wiśniowieckiego w 12 wsiach, które wchodziły wcześniej w skład fortuny rodu Świerszczów z Olchowca ${ }^{46}$. Warto przy tej okazji zwrócić uwagę na to, że Józef Wolff, autor słynnego kompendium wiedzy o kniaziach litewsko-ruskich, uważał Annę Elżbietę za córkę Jana Świerszcza seniora (w istocie jej dziadka) i Konstancji Nowodworskiej (właściwie Konstancji Świerszczówny z Nowodworu - jej babki). Nie znał też oczywiście szczegółów jej biografii przytoczonych przez K. Pułaskiego ${ }^{47}$. Wszystkie ustalenia J. Wolffa powtórzyła niemal dosłownie Ilona Czamańska w najnowszej monografii rodu książąt na Wiśniowcu ${ }^{48}$. Ze związku z Konstantym Wiśniowieckim Halsz-

${ }^{44}$ Por. AGAD, MK 99, f. 343v-344v (Lublin 1 VII 1566); MRPS, t. V, cz. 1, nr 3296 i 3297 .

${ }^{45}$ Dodajmy również, że najpewniej właśnie w 1566 lub też w 1567 r., więc wówczas, kiedy Halszka Świerszczówna stawała przed sąem grodzkim we Lwowie, jej matka ponownie została wdowa.. Utraciwszy drugiego męża, nie miała już powodu, by popierać małżeństwo córki z jego niewątpliwym krewnym - Florianem Piaseckim.

${ }^{46}$ Por. Źródła dziejowe, t. XIX, s. 222-224. Warto wspomnieć, że pobór w województwie podolskim rozpoczęto wybierać po 11 listopada $1569 \mathrm{r}$. Oznacza to, że niespełna 15-letnia Anna Elżbieta Świerszczówna mogła wyjść za kniazia Konstantego Wiśniowieckiego krótko przed tą datą. W świetle danych rejestru poborowego Wiśniowiecki wraz z ręka swojej żony otrzymał następujące wioski - Szyszkowce (część), Żórawińce (część), Rakowce, Lechnowce, Żuczkowce, Żaglówka, Unarów, Pawlikowce, Ostapkowce (część), Oleksińce, Trościaniec (część) oraz Wołodryńce.

${ }^{47}$ Por. J. Wolff, Kniaziowie litewsko-ruscy od końca czternastego wieku, Warszawa 1895, s. 569 (tu także informacja, że Anna Elżbieta na pewno była żoną Konstantego ks. Wiśniowieckiego w 1571 r., gdy jej siostra Katarzyna ustapiła jej swoich praw do połowy wsi Płoska w województwie podolskim).

${ }^{48}$ Por. I. Czamańska, Wiśniowieccy. Monografia rodu, Poznań 2007, s. 103. 
ka Świerszczówna doczekała się dwójki dzieci - syna Konstantego i córki Anny. Warto tu odnotować, że powtarzana przez wszystkich genealogów w ślad za Kasprem Niesieckim informacja, że Konstanty Wiśniowiecki junior, od 1638 r. wojewoda ruski, zmarł w roku 1641 w wieku 77 lat, jest nieprawdziwa ${ }^{49}$. Nie mógł on bowiem urodzić się w roku 1564, gdyż w tym czasie jego matka była jeszcze dzieckiem, a jej małżeństwo $z$ ojcem Konstantego zostało zawarte dopiero pięć lat później. Najstarszy syn Halszki Świerszczówny z Olchowca przyszedł więc na świat najwcześniej w 1570 r. Równie dobrze mógł się jednak urodzić nawet cztery lata później. Jego siostra, Anna ks. Wiśniowiecka została w przyszłości żoną Jana Zamoyskiego, kasztelana chełmskiego i strażnika koronnego, który poległ w walce z Tatarami w 1618 r. Sama Anna Elżbieta ze Świerszczów ks. Wiśniowiecka owdowiała w początkach $1574 \mathrm{r} \cdot{ }^{50}$ Wyszła następnie za mąż za Jana Ostroroga herbu Nałęcz, od 1576 r. podczaszego koronnego (w 1577 r. spisali wzajemne dożywocie). Miała $z$ nim także dwoje dzieci - syna Adama Krzysztofa, zmarłego bezżennie i bezpotomnie po 1607 r., oraz córkę Zofię (zm. p. 1617), od roku 1604 żonę Maksymiliana Przerembskiego (zm. 1639), z czasem wojewody łęczyckiego $^{51}$. Anna Elżbieta ze Świerszczów Ostrorogowa zmarła kilka godzin po śmierci swojego drugiego męża - najpewniej 27 lutego 1582 r. ${ }^{52}$

49 Por. K. Niesiecki, op. cit., t. IX, Lipsk 1842, s. 359; J. Wolff, op. cit., s. 570; W. Dworzaczek, op. cit., t. II, tabl. 176; I. Czamańska, op. cit., s. 147. Dodatkowym potwierdzeniem tego, że Konstanty ks. Wiśniowiecki nie urodził się w 1564 r., jest podana przez J. Wolffa informacja, że do 1584 r. opiekunem dzieci starosty żytomierskiego był jego brat, wojewoda wołyński Andrzej ks. Wiśniowiecki, a po jego śmierci opiekę tę przeją pochodzący $z$ innej linii rodu, Aleksander ks. Wiśniowiecki. Gdyby w chwili śmierci stryja Konstanty junior miał już 20 lat, z pewnościa nie potrzebowałby nowego opiekuna. Por. J. Wolff, op. cit., s. 570.

${ }^{50}$ Konstanty ks. Wiśniowiecki zmarł w pierwszych miesiącach 1574 r. Datę jego śmierci można w przybliżeniu ustalić na podstawie daty nominacji kolejnego starosty żytomierskiego, którym został Michał ks. Czartoryski. Zdaniem I. Czamańskiej Czartoryski został starostą żytomierskim 12 V 1574 r., por. eadem, op. cit., s. 103.

${ }^{51}$ Por. M.B. To pols ka, Ostroróg Jan, [w:] PSB, t. XXIV, Wrocław 1979, s. 505506 (tu jednak błędne stwierdzenie, że Halszka Świerszczówna wyszła za Ostroroga przed 1572 r.); Biblioteka Kórnicka PAN [dalej: BKPAN], Teki Dworzaczka [dalej: TD], Grodzkie i Ziemskie [dalej: GiZ], Poznań, Relacje, XVI wiek, 11934 (Nr. 1398), 1577, f. 740 (Jan Ostroróg, podczaszy koronny i Elżbieta z Olchowca, dożywocie); W. Dw orzaczek, op. cit., t. II, tabl. 105 (tu informacja, że Jan Ostroróg poślubił Annę Elżbietę Świerszczównę p. 1578 r.); J. Byliński, Przerębski (Przerembski) Maksymilian, [w:] PSB, t. XXVIII, s. 758-762.

${ }^{52}$ Por. M.B. To polska, op. cit., s. 506 (tu data śmierci Jana Ostroroga); Bibliografia polska Karola Estreichera, wyd. S. Estreicher, t. XXVI, Kraków 1915, 
Młodsza córka Jana Świerszcza juniora i Anny Lanckorońskiej - Katarzyna wyszła za syna swojego opiekuna - Michała Jazłowieckiego herbu Abdank, starostę chmielnickiego. W 1575 r. zabezpieczył on na swoich dobrach oprawę żony w wysokości 15 tys. złp. W tym samym czasie Anna $z$ Olchowca, bezdzietna wdowa po Janie Dzietrzychu, siostra jej dziada - Jana Świerszcza seniora zapisała Katarzynie wszystkie swoje dobra. Młodsza córka Anny Lanckorońskiej zmarła bezdzietnie w $1581 \mathrm{r}$. W roku następnym zmarł również jej mąż ${ }^{53}$. Cała scheda po młodszej Świerszczównie przypaść miała po śmierci Michała Jazłowieckiego dzieciom jej nieżyjącej już siostry - Konstantemu i Annie ks. Wiśniowieckim oraz Adamowi Krzysztofowi i Zofii Ostrorogom. Przejęcie spadku po Katarzynie z Olchowca Jazłowieckiej okazało się jednak zadaniem nad wyraz trudnym. W 1584 r. opiekunowie nieletnich dzieci Anny Elżbiety ze Świerszczów $1^{\circ}$ v. Wiśniowieckiej $2^{\circ}$ v. Ostrorogowej wystapili $z$ prawnymi pretensjami do Mikołaja Jazłowieckiego, brata i spadko-

s. 505 (tu informacja, że Anna Elżbieta ze Świerszczów Ostrorogowa zmarła kilka godzin po śmierci swojego męża). W wydanych drukiem kazaniach wygłoszonych na pogrzebie obojga Ostrorogów jako datę ich śmierci podano 27 IV 1582 r. Por. P. Artomiusz, Kazania Pogrzebne Nad zacnemi ciały Jego Mści Pana Jana Grabi z Ostroroga Podczaszego Koronnego i starosty stężyckiego, y Jej Mości Pani Helszki z Olchowca Świerszczówney Podczaszyny Koronney, którzy roku 1582 dnia 27 Aprilis w Panu zasnęły, [Kryłów] 1582. Tę samą datę śmierci Halszki ze Świerszczów Ostrorogowej podaje również I. Czamańska. Por. eadem, op. cit., s. 103. Wbrew, wydawałoby się, niepodważalnemu świadectwu Artomiusza zdecydowanie bardziej prawdopodobna jest jednak data lutowa. Dnia $12 \mathrm{~V} 1582 \mathrm{r}$. przebywający wówczas w Wilnie Stefan Batory ustanowił bowiem opiekę nad nieletnimi dziećmi podczaszostwa koronnych - Adamem Krzysztofem i Zofią. Opiekunami obojga zostali m.in. Stanisław Górka, wojewoda poznański, Marcin Ostroróg-Lwowski, kasztelan kamieński, Mikołaj Tworowski z Buczacza, starosta barski, oraz Stanisław Lanckoroński, starosta skalski, i jego brat Mikołaj. Obecność obu Lanckorońskich w gronie opiekunów młodych Ostrorogów stanowi kolejne potwierdzenie tego, że matką Anny Elżbiety Świerszczówny była Anna Lanckorońska, rodzona siostra Stanisława i Mikołaja. Tego samego dnia spadkobiercy Jana Ostroroga otrzymali potwierdzenie, że dokonano rozliczenia należności za dzierżawę starostwa stężyckiego, a 14 V 1582 r. król nadał Adamowi Krzysztofowi wieś Płoskę i połowę innej wsi na Podolu, czyli dobra, które użytkowała do swojej śmierci jego matka. Por. BKPAN, TD, GiZ, Poznań, Inskrypcje, XVI wiek, część 2, 9366 (Nr 939), 1582, f. 352v-353; AGAD, MK 127, f. 52v. Raczej trudno wyobrazić sobie, żeby wszystkie te działania mogły zostać podjęte już w dwa tygodnie po śmierci podczaszego koronnego i jego małżonki.

${ }^{53}$ Por. K. Pułaski, op. cit., s. 77-78; W. Dworzaczek, op. cit., t. II, tabl. 110; R. Żelewski, Jazłowiecki Jerzy, [w:] PSB, t. XI, Wrocław-Warszawa-Kraków 1964-1965, s. 123 (tu błędna informacja, że Michał Jazłowiecki ożenił się z Katarzyną Świerczkówną, co miało nastąpić w 1576 r.). 
biercy Michała. Stwierdzili przy tej okazji, że nieżyjący już Michał Jazłowiecki wymógł na swojej żonie zrzeczenie się wszelkich pretensji do spadkobierców zmarłego w 1575 r. ojca, Jerzego Jazłowieckiego, niegdyś jej opiekuna, w sprawie o niewypłacenie należnych jej dochodów (ocenianych na 20 tys. złp) za lata, kiedy zarządzał dobrami Świerszczów. Drugi zarzut dotyczył poczynań o dużo większym ciężarze gatunkowym. Opiekunowie prawowitych spadkobierców Katarzyny Jazłowieckiej twierdzili bowiem, że Michał Jazłowiecki, nie mogac otrzymać od swej żony prawnego zapisu na swoja korzyść bez zgody jej rodziny, zawarł umowę ze swoim krewnym, Stanisławem Potockim i wymógł na żonie tuż przed jej śmiercią, żeby wieczystym zapisem uczyniła donację temuż Potockiemu wszystkich swoich dóbr podolskich, pozostawiwszy na nich dożywocie mężowi. Jest sprawą oczywistą, że opiekunowie młodych Wiśniowieckich i Ostrorogów żądali zwrotu wszystkich tych posiadłości, a straty swoich pupilów $z$ tego tytułu wycenili na ogromna kwotę 200 tys. złp. Autorzy pozwu twierdzili również, że Katarzyna Jazłowiecka tuż przed śmiercią zapisała Potockiemu sumę 15 tys. złp swojej oprawy, która była zabezpieczona na dobrach jej męża, co stanowiło jaskrawe pogwałcenie interesu jej prawnych spadkobierców ${ }^{54}$. Co jednak wydaje się w tym wszystkim najbardziej zaskakujace, to fakt, że Michał Jazłowiecki, inicjator wszystkich opisanych tu działań, podejmowanych $z$ ewidentnym naruszeniem prawa, zmarł wkrótce po swojej żonie i jedynym beneficjentem jego zabiegów okazał się Stanisław Potocki. Akt donacji na jego korzyść podolskich dóbr Świerszczów został wniesiony do akt grodzkich lwowskich i kamienieckich oraz ziemskich przemyskich w $1581 \mathrm{r}$. W roku 1588 Potocki postarał się natomiast o zamieszczenie wszystkich dokumentów dotyczących tej transakcji w aktach kancelarii koronnej ${ }^{55}$. W tym miejscu pozostaje nam tylko stwierdzić, że zabiegi Wiśniowieckich i Ostrorogów o odzyskanie spornych ma-

54 Por. K. Pułaski, op. cit., s. 78-79.

55 Por. AGAD, MK 140, f. 137-148. Warto tu dodać, że hojna donacja Katarzyny ze Świerszczów Jazłowieckiej na rzecz Stanisława Potockiego obejmowała część miasta Gródka alias Bedrzychowa, miasto Zawale i ponad 30 wsi. Znaczna część tych wiosek znajdowała się jednak w rękach posesorów zastawnych. Dodajmy także, że Potocki był synem Jakuba (zm. 1551), podkomorzego halickiego, i jego drugiej żony, Druzjanny Jazłowieckiej. Jego matka była rodzona siostra wojewody ruskiego Jerzego Jazłowieckiego, ojca Michała, starosty chmielnickiego. Por. H. Kowalska, Potocki Jakub, [w:] PSB, t. XXVIII, s. 18; W. Dworzaczek, op. cit., t. II, tabl. 110, 141. 
jątków zakończyły się jedynie połowicznym sukcesem, gdyż Potoccy $z$ linii Stanisława utrzymali w swoich rękach znaczną część dawnych dóbr Świerszczów, które zostały wymienione we wspomnianym tu akcie donacji dokonanej przez Katarzynę z Olchowca Jazłowiecką.

Omówienie losów dwóch córek Anny Lanckorońskiej z jej pierwszego małżeństwa nie zamyka bynajmniej naszych rozważań poswięconych tytułowej bohaterce tego opracowania. Okazuje się bowiem, że jej drugie małżeństwo $z$ nieznanym $z$ imienia Piaseckim herbu Janina nie trwało długo i - jak można przypuszczać - było bezdzietne. Najpewniej już w 1567 r. Anna z Brzezia została żona Mikołaja Herburta $z$ Fulsztyna herbu własnego ( $z$ posiadającej znaczne dobra na Podolu linii na Dziedziłowie), w przyszłości wojewody ruskiego ${ }^{56}$. Co ciekawe, już Kasper Niesiecki, który notabene mocno zagmatwał genealogię podolskiej gałęzi Herburtów, zamieścił w swoim herbarzu informację, że pierwszą żoną

${ }^{56}$ Mikołaj Herburt (zm. 1602) był synem Jana (zm. 1553), podkomorzego kamienieckiego i starosty barskiego, oraz Zofii Dąbrowskiej z Tarnowca, wnukiem Mikołaja Herburta, wojskiego kamienieckiego, i Elżbiety z Chodorostawu Chodorowskiej oraz Baltazara Dąbrowskiego z Tarnowca i Barbary Herburtówny-Odnowskiej. Pierwszą żona jego dziadka - Mikołaja, wojskiego kamienieckiego, była nieznana $z$ imienia córka Michała Świerszcza $z$ Nowodworu. Dzięki temu małżeństwu Herburtowie weszli w posiadanie części Gródka z przyległymi wsiami. Mikołaj Herburt był dobrym i doświadczonym żołnierzem. Stosunkowo szybko piął się też po szczeblach kariery urzędniczej. W 1577 r. został chorążym lwowskim, w 1581 r. podkomorzym halickim, a w $1588 \mathrm{r}$. wojewoda podolskim. W tym samym roku otrzymał od Zygmunta III nominację na urząd wojewody ruskiego. Por. R. Żelew ski, Herburt Mikołaj z Dziedziłowa, [w:] PSB, t. IX, Wrocław-Warszawa-Kraków 1960-1961, s. 449-450; A. Boniecki, op. cit., t. VII, Warszawa 1904, s. 261. Obaj autorzy podają nieprawdziwą informację, że w 1588 r. Herburt został starostą barskim. W rzeczywistości próbował on dokonać wymiany starostwa tłumackiego na barskie, zawierając umowę w tej sprawie $z$ Mikołajem Buczackim Tworowskim. Por. AGAD, MK 135, f. 65-67 (Kraków 16 VI 1588). Ostatecznie jednak Tworowski odstapił starostwo barskie Stanisławowi Golskiemu. Warto też dodać, że R. Żelewski przyjął, że Mikołaj Herburt urodził się ok. 1544 r. Jego zdaniem, tocząc spór prawny ze stryjem Marcinem w 1562 r., musiał mieć skończone 18 lat. W rzeczywistości Mikołaj mógł się urodzić nawet kilka lat wcześniej. Ślub rodziców jego matki - Baltazara $z$ Tarnowca Dąbrowskiego i Barbary Herburtówny $z$ Odnowa - odbył się bowiem w 1517 r. Zofia z Tarnowca Herburtowa przyszła więc na świat ok. 1520 r. i mogła zostać żona podkomorzego podolskiego Jana Herburta nawet przed 1540 r. Dodajmy także, że jeśli starszy syn wojewody ruskiego - Jan rzeczywiście urodził się w 1568 r., to można założyć, że Herburt poślubił jego matkę w 1566 lub też, co wydaje się bardziej prawdopodobne, w 1567 r. Por. K. Niesiecki, op. cit., t. IV, Lipsk 1839, s. 354 (tu wzmianka, zaczerpnięta $z$ herbarza Szymona Okolskiego, że Jan Herburt zmarł w 1626 r. w wieku 58 lat); S. Cy nars ki, Herburt Jan z Fulsztyna, [w:] PSB, t. IX, s. 445-446. 
wojewody ruskiego była Lanckorońska herbu Zadora ${ }^{57}$. Kazimierz Pułaski ustalił z kolei, że matka starszego syna wojewody ruskiego - Jana Herburta była Anna Lanckorońska ${ }^{58}$. Nie podał jednak żadnych szczegółów dotyczących jej pochodzenia. Nie wiedział, że Anna Lanckorońska, żona Jana Świerszcza juniora oraz nieznanego $z$ imienia Piaseckiego, i Anna Lanckorońska, żona Mikołaja Herburta, to jedna i ta sama osoba. Dodajmy także, że o małżeństwie Mikołaja Herburta $z$ przedstawicielka rodu Lanckorońskich nie wspominają ani Adam Boniecki, ani też Seweryn Uruski ${ }^{59}$. Wzmianki o niej pojawiaja się natomiast w zamieszczonych w Polskim słowniku biograficznym biogramach Mikołaja i Jana Herburtów ${ }^{60}$. Nawet gdybyśmy nie dysponowali źródłowym potwierdzeniem faktu, że wdowa po Świerszczu i Piaseckim wyszła po raz trzeci za mąż za Mikołaja Herburta, to $z$ trudem tylko moglibyśmy przyjąc, że w nie nazbyt przecież rozrodzonej w owym czasie rodzinie Lanckorońskich pojawiła się w tym samym czasie i na tym samym terenie jeszcze jedna, nieodnotowana w herbarzach Anna. Na szczęście jesteśmy w posiadaniu jednoznacznego świadectwa potwierdzającego fakt, że Anna $z$ Brzezia Lanckorońska, córka Hieronima, starosty skalskiego była żona Mikołaja Herburta. Krótka wzmianka o niej znajduje się bowiem w wydanej w 1578 r. w Krakowie pracy Bartłomieja (Bartosza) Paprockiego ${ }^{61}$. Ten szesnastowieczny genealog i heraldyk wśród najwybitniejszych przedstawicieli rodów szlacheckich

57 Por. K. Niesiecki, op. cit., t. IV, s. 354. Warto w tym miejscu zaznaczyć, że Niesiecki pomylił Jana Herburta, podkomorzego kamienieckiego, ojca wojewody ruskiego Mikołaja, z kasztelanem sanockim Janem Herburtem (zm. 1577), ojcem słynnego rokoszanina Jana Szczęsnego (zm. 1616). Samemu Mikołajowi przypisał $z$ kolei nieznaną $z$ imienia córkę, żonę Balcera Stanisławskiego. Por. ibidem, s. 352-354. W rzeczywistości żoną Stanisławskiego była Elżbieta Herburtówna, siostra wojewody Mikołaja.

${ }^{58}$ Por. K. Pułaski, op. cit., s. 90, 99. Zaznaczmy jednak, że w innym miejscu tej pracy znalazła się informacja, że matka Jana Herburta była druga żona wojewody ruskiego, Zofia z Chodorostawu Żórawińska. Por. ibidem, s. 95.

59 Por. A. Boniecki, op. cit., t. VII, s. 261; S. Uruski, A.A. Ko siń ski, A. Włodarski, op. cit., t. V, Warszawa 1908, s. 132 (tu błędna informacja, że matka Jana Herburta, starszego syna wojewody ruskiego Mikołaja, była Zofia z Chodorostawu Żórawińska).

${ }^{60}$ Por. R. Żelewski, Herburt Mikołaj..., s. 449 (tu jednak niezbyt precyzyjne stwierdzenie, że Mikołaj Herburt z małżeństw „z Zofią z Chodorostawu Żórawińska i Anną Lanckorońską miał dwóch synów: Jana, przyszłego kasztelana kamienieckiego, i Mikołaja"); S. Cynar s ki, Herburt Jan..., s. 445.

${ }^{61}$ Por. W. Dworzaczek, Paprocki Bartłomiej (Bartosz), [w:] PSB, t. XXV, Wrocław 1980, s. 177-180. 
pieczętujących się herbem Zadora wymienił trójkę dzieci zmarłego w 1569 r. Hieronima Lanckorońskiego, zamieszczajac na kartach swego dzieła następujące zapisy: „Stanisław Lanckoroński, starosta skalski. 1578”; „Mikołaj Lanckoroński, starosty skalskiego brat. 1578”; „Herbortowa, siostra tego starosty rodzona”62.

Nie ulega najmniejszej nawet wątpliwości, że Anna z Brzezia, wdowa po Piaseckim, wyszła za Mikołaja Herburta. Być może nastapiło to w 1567 r. Z pewnością wniosła swojemu trzeciemu mężowi dobra czarnoostrowskie, na których miała dożywocie. W rejestrze poborowym województwa podolskiego z 1569 r. nie odnotowano niestety ani miasta Czarnego Ostrowa, ani też żadnej wsi $z$ tego klucza. Nie możemy więc jednoznacznie potwierdzić tego, że Lanckorońska była w tym czasie żona Herburta. Jako Herburtowa została jednak odnotowana już w styczniu następnego roku, gdy Marcin Herburt (zm. 1570), wojski kamieniecki i starosta barski, scedował na swojego bratanka Mikołaja i jego żonę Annę z Brzezia wsie królewskie Tarnawę i Ciołkowice w powiecie kamienieckim ${ }^{63}$. Kolejna wzmianka źródłowa o Annie $z$ Brzezia Herburtowej pojawia się w roku 1574, przy okazji regulowania spraw zwiazanych $z$ wypłata posagu Elżbiety Herburtówny, siostry Mikołaja, która kilka lat wcześniej została wydana za Jana Pileckiego herbu Leliwa (zm. 1574), starostę horodelskiego. Dopiero w marcu 1574 r. Jan Pilecki oprawił

${ }^{62}$ Por. B. Paprocki, Gniazdo cnoty. Zkad Herby Rycerstwa sławnego Krolestwa Polskiego, Wielkiego Księstwa Litewskiego, Ruskiego, Pruskiego, Mazowieckiego, Zmudzkiego, y inszych Państw do tego Krolestwa należących Książąt, y Panów, poczatek swoy maia, Kraków 1578, s. 1001.

${ }^{63}$ Marcin Herburt był młodszym bratem Jana, podkomorzego kamienieckiego i starosty barskiego. W 1553 r. obją po nim starostwo barskie, a w wydanym wówczas przywileju królewskim został określony jako brat rodzony poprzedniego starosty. Żoną Marcina była Katarzyna Krotoska, córka Jana, wojewody inowrocławskiego, która owdowiawszy, wyszła ponownie za mąż za Jana Hlebowicza, wojewodę trockiego. Marcin Herburt miał z nią dwie córki - Elżbietę, żonę Stanisława Lanckorońskiego, starosty skalskiego (brata Anny z Brzezia Herburtowej), oraz Zofię $1^{\circ}$ v. za Janem Dulskim $2^{\circ}$ v. za Janem Kostka i $3^{\circ}$ v. za Janem Czarnkowskim. Por. AGAD, MK 84, f. 326-326v; MRPS, t. V, cz. 2, nr 6364; A. B o ni ecki, op. cit., t. VII, s. 261 (tu błędna informacja, że Marcin miał również syna Mikołaja, chorażego lwowskiego i podkomorzego halickiego). W rzeczywistości wspomnianym tu Mikołajem był bowiem jego bratanek, syn Jana. Warto też odnotować w tym miejscu, że H. Kotarski w biogramie Stanisława Lanckorońskiego błędnie podał, że jego żoną była Elżbieta Herburtówna, córka Jana, kasztelana sanockiego. Por. id em, Lanckoroński Stanisław..., s. 453. Akt cesji Tarnawy i Ciołkowic na rzecz Mikołaja i Anny z Brzezia Herburtów por. AGAD, MK 109, f. 398-401 (Knyszyn 26 X 1553); MRPS, t. V, cz. 1, nr 4124. 
żonie 24 tys. złp posagu i wiana na połowie swoich dóbr, ustanawiając jednocześnie opiekę nad nieletnimi dziećmi - Krzysztofem i Anna ${ }^{64}$. Przy tej samej okazji Mikołaj Herburt zapisał szwagrowi 2000 złp na dobrach dziedzicznych w ziemi lwowskiej - Dziedziłowie, Olbach, Nawczu i Sokołowie, czego dokonał za wiedzą i zgodą swojej żony - Anny Lanckorońskiej ${ }^{65}$. Możemy przypuszczać, $\dot{z}$ e Anna $z$ Brzezia Herburtowa zmarła w pierwszych tygodniach 1578 r. $Z$ pewnością nie żyła już 27 lutego tego roku, kiedy Zofia z Tarnowca Dąbrowska, wdowa po Marku Stadnickim, przekazała wsie królewskie Radymicze, Jatwięgi, Kornicę i Jagielnicę w ziemi przemyskiej oraz dzierżawę osiecką w ziemi krakowskiej chorążemu lwowskiemu Mikołajowi Herburtowi, swojemu synowi $z$ pierwszego małżeństwa $z$ Janem Herburtem, podkomorzym kamienieckim i starosta barskim ${ }^{66}$. Wspomniany tu Mikołaj Herburt to oczywiście znany nam już małżonek Anny $z$ Brzezia, a brak wzmianki o niej $\mathrm{w}$ przytoczonym tu akcie świadczy jednoznacznie o tym, że w tym czasie już nie żyła. Potwierdzenie tego faktu znajdujemy w rejestrze poborowym województwa podolskiego z 1578 r., gdzie jako właścicielki klucza czarnoostrowskiego, który w 1565 r. trzymała „pani Piasecka”, występuja jej córki z pierwszego małżeństwa - „panie Świerszczówny"67.

$Z$ małżeństwa $z$ Mikołajem Herburtem Anna Lanckorońska miała jednego syna - Jana (1568-1626), z czasem kasztelana kamienieckiego i starostę skalskiego. Przed 1596 r. poślubił on Konstancję

${ }^{64}$ Jan Pilecki ożenił się z Elżbietą Herburtówną ok. 1570 r. Jego córka - Anna urodziła się w roku 1572. W przyszłości została ona żoną Krzysztofa Kostki, starosty kościerzyńskiego, a następnie wyszła za maż za Łukasza Opalińskiego, marszałka wielkiego koronnego. Fakt, że dopiero w 1574 r. uregulowano kwestie związane $z$ wypłata posagu Elżbiety Herburtówny, jest kolejnym potwierdzeniem tego, że małżeństwo Jana Świerszcza juniora i Anny Lanckorońskiej zostało zawarte nie w roku 1556, ale kilka lat wcześniej. Dodajmy także, że Elżbieta z Herburtów Pilecka po śmierci pierwszego męża wyszła ponownie za mąż za Balcera Stanisławskiego herbu Pilawa (zm. 1610), podskarbiego wielkiego koronnego. Por. W. Dwo rzaczek, Genealogia..., t. II, tabl. 103; W. Czaplińs ki, Opaliński Łukasz z Bnina, [w:] PSB, t. XXIV, s. 92 (tu błędna informacja, że mężem Anny Pileckiej był również Jan Kostka, starosta lipieński); AGAD, MK 111, f. 352v-355 (Kraków 24 III 1574); MRPS, t. VI, wyd. M. Woźniakowa, Warszawa 1999, nr 110, 111; K. Chłapowski, Stanisławski Baltazar (Balcer), [w:] PSB, t. XLII, WarszawaKraków 2003-2004, s. 110-111.

${ }^{65}$ Por. AGAD, MK 111, f. 355-357v (Kraków 29 III 1574); MRPS, t. VI, nr 134.

${ }^{66}$ Por. AGAD, MK 118, f. 152v-154 (Warszawa 27 II 1578).

${ }^{67}$ Por. Źródła dziejowe, t. XIX, s. 274. 
Przerembską herbu Nowina, córkę Jana i Doroty Rusockiej z Rusocic herbu Zadora. Pozostawił po sobie dwóch synów - Mikołaja (zm. 1639), kasztelana kamienieckiego, i Hieronima, ostatnich męskich przedstawicieli podolskiej linii Herburtów, oraz dwie córki - Zofię, żonę Samuela Kossowskiego, i Annę Konstancję, norbertankę w Warszawie ${ }^{68}$. Owdowiały po Annie $z$ Brzezia Mikołaj Herburt ożenił się ponownie ze znacznie młodsza od siebie Zofią $z$ Chodorostawu Żórawińską herbu Korczak ${ }^{69}$. Miał z nią syna Mikołaja, starostę tłumackiego, który zmarł w czasie oblężenia Smoleńska w 1610 r. ${ }^{70}$ Wbrew twierdzeniu Kazimierza Pułaskiego, który daje

68 Por. S. Cynarski, Herburt Jan..., s. 445 (tu błędna informacja, że Jan Herburt został starosta skalskim dopiero po śmierci ojca, ok. 1603 r.); A. B oniecki, op. cit., t. VII, s. 261-262; AGAD, MK 137, f. 499v-500v (konsens królewski na cesję starostwa skalskiego, nadanego Mikołajowi Herburtowi 26 VII 1592 r., po śmierci Stanisława Lanckorońskiego, na rzecz jego syna Jana, Warszawa, 20 XII 1592); MK 140, f. 291-292 (dożywocie na wsiach Łojanowice, Żylińce, Hłuboczek i Cygany dla Jana Herburta, starosty skalskiego i jego żony Konstancji Przerembskiej, Warszawa 25 IX 1596).

${ }^{69}$ Zofia $z$ Chodorostawu Żórawińska była córką Sebastiana, kasztelana halickiego, i Elżbiety Kościeleckiej, wojewodzianki łęczyckiej. Jej matka przyszła na świat ok. 1544 r. Ona sama mogła się więc urodzić najwcześniej na początku lat sześćdziesiątych XVI w. W rzeczywistości jednak była pewnie młodsza. Jej bratem był Stanisław Źórawiński (zm. 1625), kasztelan bełski, a siostrą Anna, żona Mikołaja z Brzezia Lanckorońskiego (zm. 1597), podkomorzego podolskiego, rodzonego brata Anny, pierwszej żony wojewody ruskiego Mikołaja Herburta. Por. K. Niesiecki, op. cit., t. IV, s. 354; A. Swieżaw ski, Kościelecki (z Kościelca) Jan (Janusz), [w:] PSB, t. XIV, Wrocław-Warszawa-Kraków 1968-1969, s. 405 (tu stwierdzenie, że najmłodsze dzieci wojewody łęczyckiego - Stanisław i Elżbieta przyszły na świat po 1 VI 1543 r.); A. Boniecki, op. cit., t. VII, s. 261. Dodajmy także, że potwierdzona źródłowo wzmianka o Zofii Żórawińskiej jako żonie Mikołaja Herburta pochodzi dopiero $z$ maja 1589 r. W akcie nadania starostwa tłumackiego Mikołajowi Herburtowi (6 I 1588) nie wspomniano bowiem o jego małżonce. Dnia 25 V 1589 r. Zygmunt III rozszerzył natomiast prawo dożywocia na tej dzierżawie na Zofię z Chodorostawu Herburtową. Por. MK 133, f. 220, 391v-392 (Lublin 6 I 1588, Lublin 25 V 1589).

70 Por. R. Żelewski, Herburt Mikołaj..., s. 449; A. Boniecki, op. cit., t. VII, s. 261. Potwierdzeniem tego, że ślub rodziców Mikołaja nastapił rzeczywiście dopiero pod koniec lat osiemdziesiatych XVI w., sa perypetie związane z przejęciem przez niego starostwa tłumackiego. Co prawda, już w sierpniu $1601 \mathrm{r}$. Mikołaj i Zofia Herburtowie uzyskali konsens królewski na ustapienie Tłumacza swojemu synowi Mikołajowi, ale z pewnością zatrzymali jeszcze tę królewszczyznę w swoich rękach (być może właśnie ze względu na młody wiek syna). Por. AGAD, MK 147, f. 117v-118v. W lutym 1606 r. Zofia z Chodorostawu Herburtowa uzyskała bowiem kolejne zezwolenie królewskie na scedowanie synowi starostwa tłumackiego i można przypuszczać, że dopiero wówczas wszedł on w posiadanie tej dzierżawy. Por. AGAD, MK 150, f. 201v-203. 
mu za żonę Katarzynę z Ludzisk Ludzicką ${ }^{71}$, Mikołaj Herburt junior zmarł bezżennie i bezpotomnie.

$\mathrm{Na}$ zakończenie wypada raz jeszcze przypomnieć najważniejsze ustalenia dotyczace tytułowej bohaterki niniejszego opracowania. Anna $z$ Brzezia Lanckorońska herbu Zadora urodziła się ok. 1536/37 r. jako córka Hieronima Lanckorońskiego (zm. 1569) i jego pierwszej żony, Katarzyny Niemścianki z Krzcięcic herbu Jastrzębiec ${ }^{72}$. W 1553 lub 1554 r. poślubiła Jana Świerszcza z Olchowca herbu Jastrzębiec. Owdowiała najpóźniej w 1563 r. Być może jeszcze w tym samym roku wyszła ponownie za mąż za nieznanego $z$ imienia Piaseckiego herbu Janina ${ }^{73}$. Zapewne już $w$ roku 1566 została ponownie wdową. W 1567 r. została żona Mikołaja Herburta z Fulsztyna i Dziedziłowa herbu własnego (zm. 1602), od 1588 r. wojewody ruskiego. Anna $z$ Brzezia Herburtowa zmarła najpewniej w pierwszych tygodniach $1578 \mathrm{r}$. W tym czasie jej trzeci mąż był jeszcze tylko chorążym lwowskim. $Z$ trzech małżeństw miała trójkę dzieci - Annę Elżbietę (zm. 1582) i Katarzynę (zm. 1581) Świerszczówny z Olchowca oraz Jana Herburta (15681626), z czasem kasztelana kamienieckiego. Najstarsza córka Anny Lanckorońskiej - Halszka Świerszczówna była żoną Konstantego ks. Wiśniowieckiego (zm. 1574), starosty żytomierskiego, a następnie Jana Ostroroga (zm. 1582), podczaszego (cześnika) koronnego i starosty stężyckiego. Katarzyna ze Świerszczów poślubiła Michała Jazłowieckiego (zm. 1582), starostę chmielnickiego. Jedyny syn Anny z Brzezia - Jan Herburt ożenił się z kolei z Konstancją

${ }^{71}$ Por. K. Pułaski, op. cit., s. 99.

72 Dziadkami Anny byli: Mikołaj z Brzezia Lanckoroński (zm. 1520), cześnik sandomierski i burgrabia krakowski, Katarzyna Stadnicka h. Drużyna, Jerzy Niemsta $z$ Krzcięcic (zm. 1549) i Anna Gołuchowska h. Lis. Jej pradziadkami byli z kolei: Stanisław z Brzezia Lanckoroński (zm. 1489), marszałek nadworny koronny, Anna Kurozwęcka h. Poraj, Mikołaj Stadnicki (zm. 1490), wojewoda bełski, Barbara $z$ Niedźwiedzia i Birkowa h. Odrowąż, Jan Niemsta $z$ Krzcięcic (zm. 1488), nieznana $z$ nazwiska Barbara, Klemens Gołuchowski oraz Katarzyna Beska.

${ }^{73}$ Być może drugim mężem Anny Lanckorońskiej był zmarły przed 17 VI 1566 r. Jan Piasecki alias Przezwocki, który zastawił wieś królewską Psiec na Podolu Kasprowi Wilkowskiemu. Por. AGAD, MK 99, f. 343v-344. Można tak wnioskować na podstawie tego, że konsens królewski na wykupienie tej wsi z rak Wilkowskiego uzyskał nie kto inny, jak brat rodzony lub też stryjeczny nieżyjącego już Jana - Florian Piasecki, zapewne tożsamy z niedoszłym mężem Halszki Świerszczówny. Por. L. Birlkows ki, Podole w XVI wieku. Rysy społeczne i gospodarcze, Warszawa 1920, s. 163 (tu wzmianka o pokrewieństwie łączącym Jana i Floriana Piaseckich, którym autor przypisuje jednak nie herb Janina, a Zabawa). Rzecz jasna cała ta kwestia wymaga gruntownej weryfikacji źródłowej. 
Przerembską. Warto też pamiętać o tym, że wnukami naszej bohaterki byli: Konstanty ks. Wiśniowiecki (zm. 1641), wojewoda ruski, Anna ks. Wiśniowiecka, Adam Krzysztof Ostroróg (zm. po 1607), Zofia Ostrorożanka (zm. p. 1617), Mikołaj Herburt (zm. 1639), kasztelan kamieniecki, Hieronim Herburt oraz Zofia i Anna Konstancja Herburtówny. Jeszcze bardziej imponująco przedstawia się lista jej prawnuków ${ }^{74}$. Uwzględnienie $\mathrm{w}$ genealogiach wspomnianych tu rodzin postaci Anny z Brzezia Lanckorońskiej $1^{\circ}$ v. Świerszczowej $2^{\circ} \mathrm{v}$. Piaseckiej $3^{\circ} \mathrm{v}$. Herburtowej $z$ pewnościa pozwala rzucić nowe światło na kwestię związków rodzinnych łączących szereg wybitnych postaci życia publicznego dawnej Rzeczypospolitej u schyłku XVI i w pierwszej połowie XVII w.

${ }^{74}$ Konstanty ks. Wiśniowiecki (zm. 1641) po raz pierwszy ożenił się z Anną Zahorowską i miał z nia syna Janusza (zm. 1636), koniuszego koronnego, oraz córki Mariannę, żonę Jakuba Sobieskiego (zm. 1646), z czasem kasztelana krakowskiego, i Helenę, żonę Stanisława Warszyckiego (zm. 1681), który w 1651 r. również został kasztelanem krakowskim. Z drugiego małżeństwa Konstantego ks. Wiśniowieckiego z Urszulą Mniszchówna pochodzili synowie Jerzy (zm. 1641), starosta kamionacki, i Aleksander (zm. 1639), starosta czerkaski, oraz córka Teofila, żona Piotra Szyszkowskiego (zm. 1645), kasztelana wojnickiego. Anna ks. Wiśniowiecka poślubiła Jana Zamoyskiego (zm. 1618), kasztelana chełmskiego i strażnika koronnego, z którym miała sześciu synów: Jana Baptystę (zm. 1655), biskupa łuckiego, Władysława, franciszkanina, Maurycego, Jerzego, Zdzisława Jana (zm. 1670), kasztelana czernihowskiego, i Aleksandra (zm. 1655), strażnika koronnego, oraz córkę Annę, która wyszła za Andrzeja Górskiego (zm. 1624), wojewodę mazowieckiego. Zofia Ostrorożanka (zm. p. 1617) została żoną Maksymiliana Przerembskiego (zm. 1639), wojewody łęczyckiego, i miała z nim córki: Izabelę, pierwszą żonę Stanisława Warszyckiego, który po jej śmierci ożenił się z Helena ks. Wiśniowiecka, Mariannę $1^{\circ}$ v. za Andrzejem Czuryła, podkomorzym halickim, $2^{\circ}$ v. za Franciszkiem Bądzyńskim, Katarzynę, żonę Wojciecha Starołęskiego, kasztelana żarnowskiego i Konstancję, zakonnicę u św. Klary we Wrocławiu. Kasztelan kamieniecki Mikołaj Herburt (zm. 1639) ożenił się z Anną Żółkiewska i miał z nią córki - Konstancję, żonę Jana Fryderyka Sapiehy (zm. 1664), pisarza polnego koronnego, i Zuzannę, która wyszła za Franciszka Stadnickiego, a po jego śmierci została żoną Konstantego Leona Obodyńskiego. Hieronim Herburt poślubił Krystynę z Husiatyna Kalinowska i miał z nią córki: Helenę, żonę Samuela Konstantego Szczawińskiego (zm. 1693), kasztelana kruszwickiego, oraz Konstancję, który wyszła najpierw za Jana Strzyżewskiego, a po jego śmierci za Łukasza Kazimierza Prusinowskiego, kasztelana lubaczowskiego. Ostatnia z wnuczek Anny Lanckorońskiej - Zofia Herburtówna poślubiła Samuela Kossowskiego $z$ Głogowy, właściciela dóbr ziemskich na Podolu, i miała $z$ nim syna Kazimierza oraz córki: Zuzannę, żonę Achacego Ligęzy, kasztelana czechowskiego i Annę. 


\section{Bibliografia}

\section{ŹRÓDEA ARCHIWALNE}

Archiwum Główne Akt Dawnych w Warszawie (AGAD)

Metryka Koronna (MK) 11, 12, 14, 25, 30, 45, 58, 80, 82, 83, 84, 86, 89, 93, 95, 96, 99, 109, 111, 118, 127, 133, 137, 140, 147, 150.

\section{ŹRÓDEA DRUKOWANE}

Artomiusz P., Kazania Pogrzebne Nad zacnemi ciały Jego Mści Pana Jana Grabi z Ostroroga Podczaszego Koronnego i starosty stężyckiego, y Jej Mości Pani Helszki z Olchowca Świerszczówney Podczaszyny Koronney, którzy roku 1582 dnia 27 Aprilis w Panu zasnęły, [Kryłów] 1582.

Biblioteka Kórnicka PAN, Teki Dworzaczka

Matricularum Regni Poloniae summaria, excussis codicibus, qui in Chartophylacio Maximo Varsoviensi asservantur [MRPS], t. I, wyd. T. Wierzbowski, Warszawa 1905; t. IV, wyd. T. Wierzbowski, Warszawa 1917; t. V, cz. 1, wyd. T. Wierzbowski, Warszawa 1919; t. V, cz. 2, wyd. J. Płocha, A. Rybarski, I. Sułkowska, red. J. Sawicki, Warszawa 1961; t. VI, wyd. M. Woźniakowa, Warszawa 1999.

Paprocki B., Gniazdo cnoty. Zkąd Herby Rycerstwa sławnego Krolestwa Polskiego, Wielkiego Księstwa Litewskiego, Ruskiego, Pruskiego, Mazowieckiego, Zmudzkiego, y inszych Państw do tego Krolestwa należacych Książą, y Panów, poczatek swoy maia, Kraków 1578.

Źródła dziejowe, t. XIX (Polska XVI wieku pod względem geograficzno-statystycznym, t. VIII (Ziemie ruskie. Wołyń i Podole), wyd. A. Jabłonowski, Warszawa 1889.

\section{Opracowania}

Bibliografia polska Karola Estreichera, wyd. S. Estreicher, t. XXVI, Kraków 1915.

Birlkowski L., Podole w XVI wieku. Rysy społeczne i gospodarcze, Warszawa 1920.

Boniecki A., Herbarz polski, t. VII, Warszawa 1904; t. XIII, Warszawa 1909.

Byliński J., Przerębski (Przerembski) Maksymilian, [w:] Polski słownik biograficzny, t. XXVIII, Wrocław 1984-1985, s. 758-762.

Chłapowski K., Stanisławski Baltazar (Balcer), [w:] Polski słownik biograficzny, t. XLII, Warszawa-Kraków 2003-2004, s. 110-111.

Cynarski S., Dzieje rodu Lanckoronskich z Brzezia od XIV do XVIII wieku. Sprawy kariery urzędniczej i awansu majatkowego, Warszawa-Kraków 1996.

Cynarski S., Herburt Jan z Fulsztyna, [w:] Polski słownik biograficzny, t. IX, Wrocław-Warszawa-Kraków 1960-1961, s. 445-446.

Czamańska I., Wiśniowieccy. Monografia rodu, Poznań 2007.

Czapliński W., Opaliński Łukasz z Bnina, [w:] Polski słownik biograficzny, t. XXIV, Wrocław 1979, s. 90-93. 
Dworzaczek W., Genealogia, t. II (Tablice), Warszawa 1959.

Dworzaczek W., Paprocki Bartłomiej (Bartosz), [w:] Polski słownik biograficzny, t. XXV, Wrocław 1980, s. 177-180.

Kaniewska I., Lanckoroński Mikołaj, [w:] Polski słownik biograficzny, t. XVI, Wrocław-Warszawa-Kraków 1971, s. 446-448.

Konarski S., Pułaski Kazimierz Ferdynand, [w:] Polski słownik biograficzny, t. XXIX, Wrocław 1986, s. 395-396.

Kotarski H., Lanckoroński Mikołaj, [w:] Polski słownik biograficzny, t. XVI, Wrocław-Warszawa-Kraków 1971, s. 448.

Kotarski H., Lanckoroński Stanisław, [w:] Polski słownik biograficzny, t. XVI, Wrocław-Warszawa-Kraków 1971, s. 452-453.

Kowalska H., Potocki Jakub, [w:] Polski słownik biograficzny, t. XXVIII, Wrocław 1984-1985, s. 17-18.

Kuczyński S.M., Fedor Koriatowicz, [w:] Polski słownik biograficzny, t. VI, Kraków 1948, s. 383-384.

Niesiecki K., Herbarz polski, wyd. J.N. Bobrowicz, t. IV, Lipsk 1839; t. VI, Lipsk 1841; t. IX, Lipsk 1842.

Plewczyński M., Potocki Mikołaj, [w:] Polski słownik biograficzny, t. XXVIII, Wroclaw 1984-1985, s. 103-105.

Pułaski K., Stare osady $w$ ziemi kamienieckiej i dziedziczace $w$ nich rodziny podolskiej szlachty historycznej, [w:] idem, Szkice i poszukiwania historyczne, t. III, Kraków 1906, s. 5-120.

Słownik historyczno-geograficzny województwa krakowskiego w średniowieczu, cz. 3, z. 1, oprac. W. Bukowski, J. Kurtyka, J. Laberschek, Z. Leszczyńska-Skrętowa, F. Sikora, red. F. Sikora, Kraków 1994.

Swieżawski A., Kościelecki (z Kościelca) Jan (Janusz), [w:] Polski słownik biograficzny, t. XIV, Wrocław-Warszawa-Kraków 1968-1969, s. 404-405.

Topolska M.B., Ostroróg Jan, [w:] Polski słownik biograficzny, t. XXIV, Wrocław 1979, s. 505-506.

Uruski S., Kosiński A.A., Włodarski A., Rodzina. Herbarz szlachty polskiej, t. V, Warszawa 1908; t. VIII, Warszawa 1911.

Wolff J., Kniaziowie litewsko-ruscy od końca czternastego wieku, Warszawa 1895.

Żelewski R., Herburt Mikołaj z Dziedziłowa, [w:] Polski słownik biograficzny, t. IX, Wrocław-Warszawa-Kraków 1960-1961, s. 449-450.

Żelewski R., Jazłowiecki Jerzy, [w:] Polski słownik biograficzny, t. XI, WrocławWarszawa-Kraków 1964-1965, s. 121-123. 